\title{
Occurrence of Anopheles (Nyssorhynchus) rangeli (Gabaldon et al) and Anopheles (Nyssorhynchus) evansae (Brethes) (Diptera: Culicidae) in an Eutrophized Dam
}

\author{
Eduardo D Wermelinger ${ }^{1}$, Ciro V Benigno ${ }^{1}$, Roberto N M Machado ${ }^{1}$, Teresa F S Nascimento ${ }^{2}$, \\ Aldo P Ferreira ${ }^{3}$, Antônio M Meira ${ }^{1}$, Marcos B Souza ${ }^{1}$, José C Zanuncio ${ }^{4}$ \\ ${ }^{1}$ Depto de Ciências Biológicas, Escola Nacional de Saúde Pública; ${ }^{2}$ Depto de Entomologia; ${ }^{3}$ Centro de Estudos da \\ Saúde do Trabalhador e Ecologia Humana (CESTEH/ENSP). IOC/FIOCRUZ, Rua Leopoldo Bulhões 1480, 21041-210 \\ Manguinhos, RJ, Brasil \\ ${ }^{4}$ Depto de Biologia Animal, Univ Federal de Viçosa, 36571-000 Viçosa, MG, Brasil \\ edw@ensp.fiocruz.br; zanuncio@ufv.br \\ Edited by Álvaro Eiras - UFMG
}

Neotropical Entomology 39(3):449-450 (2010)

\begin{abstract}
This is the first record of immature stages of species belonging to the subgenus Nyssorhynchus (Blanchard) in eutrophized breeding habitats. Larvae of Anopheles (Nys.) evansae (Brethes), Anopheles (Nyssorhynchus) rangeli (Gabaldon et al), Culex nigripalpus (Theobald) and Culex quinquefasciatus (Say) (Diptera: Culicidae) were collected in a rural eutrophized dam in Rio de Janeiro State, in Southeastern Brazil. Eutrophication was substantiated by the low diversity of mosquitoes, the high incidence of $C x$. quinquefasciatus (42\%) and of Daphinia sp. and, the high levels of both organic nitrogen $(0.28 \mathrm{mg} / \mathrm{l})$ and total phosphorus $(0.02 \mathrm{mg} / \mathrm{l})$.
\end{abstract}

KEY WORDS: Brazil, polluted breeding habitat

The subgenus Nyssorhynchus (Blanchard) includes the main Neotropical vectors of malaria in the genus Anopheles, such as A. darlingi (Root) and A. aquasalis (Curry). Immatures of Nyssorhynchus are usually found in natural and man-made breeding habitats (Deane et al 1948, Forattini, 1962, 2002, Faran \& Linthicum 1981, Rubio-Palis 2000). Nonetheless, there are no indications Nyssorhynchus species are able to exploit eutrophized breeding habitats. Eutrophication is one of the most important human-induced modifications affecting aquatic systems in the biosphere (Pinto-Coelho et al 2005). In fact, eutrophication in lakes, reservoirs, estuaries and rivers is a worldwide increasing phenomenon. Water eutrophication has been assessed by using individual parameters (e.g., total phosphorus, total nitrogen) or comprehensive indices (e.g., total nutrient status index). Among the factors influencing water eutrophication, nutrient enrichment, hydrodynamics, and environmental factors are the major ones. Environmental factors such as temperature, salinity, carbon dioxide, element balance, and microbial biodiversity can be easily assessed on eutrophicated water bodies (Yang et al 2008).

Mosquito larvae and pupae were collected in a rural artificial dam in the municipality of Paraíba do Sul, Rio de Janeiro State, in Southeast of Brazil (22¹3'27.49”S 4314'43.97’'W, $529 \mathrm{~m}$ ) from December 2004 to December 2005. The estimated dam's area is of $560 \mathrm{~m}^{2}$, surrounded by farms dealing with animal and agricultural activities. Mosquito immature collections were done once a month by dipping a white enamel pan on three portions of the margins of the dam. In each portion three dippings were made in a total of nine dippings per month. Third and fourth instars and pupae were reared up to adults and identified based on their morphology (Consoli \& Oliveira 1994, Forattini 2002).

A total of 241 adult mosquitoes were obtained during twelve-month larval collections. The identified species were Culex quinquefasciatus (Say) (42.3\%), Anopheles evansae (Brethes) (24.5\%), Culex nigripalpus (Theobald) (19.1\%) and Anopheles rangeli (Gabaldon et al) (14.1\%). Even though there are different interpretations on the limits of concentration of phosphorus for each trophic level, the low diversity of mosquito species, the high incidence of $C x$. quinquefasciatus and Daphinia sp., the high levels of organic nitrogen $(0.28 \mathrm{mg} / \mathrm{l})$ and total phosphorus $(0.02 \mathrm{mg} / \mathrm{l})$ indicated dam eutrophication. Eutrophication of this dam in particular is very likely to be related to the animal and plant agricultural activities in the dam's margins.

Former studies were carried out on the biology of Nyssorhynchus group without, however, measuring trophic levels of breeding habitats. Previous observations were mostly focused on breeding habitat size, type, presence of vegetation, phytoplankton, chlorine and pH levels (Deane et al 1948, Forattini, 1962, 2002, Faran \& Linthicum 1981, Rubio-Palis 2000). Several species of Nyssorhynchus have been reported on breeding habitats rich in organic matter, including $A$. rangeli and A. evansae (Galvão et al 1942, Deane et al 1948, Forattini 1962, Faran 1980) or with conditions indicative of an eutrophicated environment (Buxton 1934). However, 
these previous reports are inaccurate and insufficient to characterize eutrophized trophic levels, probably because organic matter is mostly associated with the visual amount of vegetation. These reports are therefore insufficient to show the potentiality for the Nyssorhynchus species to explore eutrophicated environments.

This is the first report for two species of the subgenus Nyssorhynchus, i.e., A. rangeli and A. evansae in eutrophized breeding habitats. This characterization is important to monitor the capacity to explore eutrophized breeding habitats, posing major dispersion risks for those species that are potential malaria vectors.

\section{Acknowledgments}

To Maria Goreti Rosa-Freitas for text correction and revision.

\section{References}

Buxton P A (1934) Further studies upon chemical factors affecting the breeding of Anopheles in Trinidad. Bull Entomol Res 25: 491-494.

Consoli R A G B, Oliveira R O (1994) Principais mosquitos de importância sanitária no Brasil. FIOCRUZ, Rio de Janeiro, 225p.

Deane L M, Causey O R, Deane M P (1948) Notas sobre a distribuição e a biologia dos anofelinos das regiões nordestina e amazônica do Brasil. Rev Serviço Especial Saúde Pública 1: 1-965.

Faran M E (1980) A revision of the Albimanus Section of the subgenus Nyssorhynchus of Anopheles. Contrib Am Entomol Inst 15: 1-214.

Faran M E, Linthicum K J (1981) A handbook of the Amazonian species of Anopheles (Nyssorhynchus) (Diptera: Culicidae). Mosquito Sys 13: 1-81.

Forattini O P (1962) Entomologia médica. Vol 1, Fac. Hyg Public Health, São Paulo, 662p.

Forattini O P (2002) Culicidologia médica. Vol 2, Edusp, São Paulo, 548p.

Galvão A L, Damasceno R G, Marques A P (1942) Algumas observações sobre a biologia dos anofelinos de importância epidemiológica em Belém do Pará. Arq Hyg 12: 51-111.

Pinto-Coelho R M, Bezerra-Neto J F, Morais Jr C A (2005) Efeitos da eutrofização sobre o tamanho e a biomassa do zooplâncton crustáceo em um reservatório tropical. Braz J Biol 65: 325-338.

Rubio-Palis Y (2000) Anopheles (Nyssorhynchus) de Venezuela - Taxonomia, bionomía e importancia médica. Esc Malaríol Saneam Amb, Caracay, 118p.

Yang C E, Wu X, Hao H L, He Z L (2008) Mechanisms and assessment of water eutrophication. J Zhejiang Univ Sci B 9: 197-209.

Received 14/XI/08. Accepted 22/IV/09. 